\title{
EFFICACY OF NEW CHEMISTRY INSECTICIDES ON THE HAEMOCYTES OF MAIZE STEM BORER, CHILO PARTELLUS, UNDER LABORATORY CONDITIONS
}

\author{
Saeed Alam ${ }^{1}$, Muhammad Tariq ${ }^{1}$, Asim Gulzar ${ }^{1}$, Rabia Ali' $^{2}$, Shanza Khan², Mubeen Iqbal ${ }^{1}$ \\ ${ }^{1}$ Department of Entomology, Pir Mehr Ali Shah Arid Agriculture University, Rawalpindi, Pakistan. \\ 2 Insect Pest Management Program, Institute of Plant \& Environmental Protection, National Agricultural Research \\ Centre, Park Road, Islamabad.
}

\section{ART I CLE IN F O}

\section{Article history}

Received: 29th January, 2020

Revised: $12^{\text {th }}$ August, 2020

Accepted: $16^{\text {th }}$ August, 2020

\section{Keywords}

Chilo partellus

Haemocytes

Belt

Match

Radiant

Chlorfenpyr

\section{A B S T R A C T}

In the present study, four new chemistry insecticides (Radiant, Chlorfenapyr, Belt and Match) were used to evaluate the haemocytological activity of Chilo partellus. LC $_{50}$ and $\mathrm{LC}_{60}$ values of each insecticide were calculated by bioassay test. After the application of Radiant insecticide, the total haemocytes count immediately increased (78548.5 cells $/ \mathrm{mm}^{3}$ ) as compared to normal $\left(71255\right.$ cells $/ \mathrm{mm}^{3}$ ), however, after 30 minutes decreased to $\left(71694\right.$ cells $/ \mathrm{mm}^{3}$ ) and after 60 minutes of interval, the total haemocytes count again increased $\left(80215\right.$ cell $\left./ \mathrm{mm}^{3}\right)$. Percent plasmotcytes increased from untreated to $26 \%$, while the spherulocytes, granulocytes, prohaemocytes and cystocytes also fluctuated from the untreated as $26 \%, 6.75 \%$, $33 \%$ and $3.75 \%$ respectively. After the application of Chlorfenpyr insecticide, the total Haemocytes count immediately increased $\left(80920.75\right.$ cells $\left./ \mathrm{mm}^{3}\right)$ as compared to normal $\left(71255\right.$ cells $\left./ \mathrm{mm}^{3}\right)$, however after 30 minutes decreased to $(71155$ cells $/ \mathrm{mm}^{3}$ ) and after 60 minutes, the total haemocytes count again increased (84100 cell $/ \mathrm{mm}^{3}$ ). Percent plasmotcytes increased from untreated to $36 \%$, while the spherulocytes, granulocytes, prohaemocytes and cystocytes also fluctuated from the untreated to $23.5 \%, 5.5 \%, 29 \%$ and $1.5 \%$ respectively. After the application of Belt insecticide, the total haemocytes count immediately increased $\left(87200\right.$ cells $\left./ \mathrm{mm}^{3}\right)$ as compared to normal $\left(71255\right.$ cells $\left./ \mathrm{mm}^{3}\right)$ and after 30 minutes decreased $(71270$ cells $/ \mathrm{mm}^{3}$ ) and after 60 minutes, the total haemocytes count again increased (89640 cell $/ \mathrm{mm}^{3}$ ). Percent plasmotcytes increased from untreated to $36 \%$, while the spherulocytes, granulocytes, prohaemocytes and cystocytes also fluctuated from the untreated to $32.5 \%, 8.5 \%, 17.25 \%$ and $4.75 \%$ respectively. After the application of Match insecticide, the total haemocytes count immediately increased (87500 cells $\left./ \mathrm{mm}^{3}\right)$ as compared to normal $\left(72155\right.$ cells $\left./ \mathrm{mm}^{3}\right)$ while after 30 minutes decreased (72190 cells $\left./ \mathrm{mm}^{3}\right)$ and after 60 minutes, the total haemocytes count again increased ( $99800 \mathrm{cell} / \mathrm{mm}^{3}$ ). Percent plasmotcytes increased from untreated to $33 \%$, while the spherulocytes, granulocytes, prohaemocytes and cystocytes also fluctuated from the untreated to $31 \%, 14 \%, 23 \%$ and $4 \%$ respectively.

Corresponding Author: Muhammad Tariq

Email:mtariq@uaar.edu.pk

(C) 2020 EScience Press. All rights reserved. 


\section{INTRODUCTION}

Maize (Zea mays) is one of the most important cereal crops and ranks $3^{\text {rd }}$ in the world cereal production after wheat and rice (Chouraddi et al., 2016; Manjunath and Mallapur, 2017). Maize is widely used as staple food, animal feed and fodder in the world. The grains of maize crop are widely used as raw materials for many textile and industrial products and have high nutritional values. In Pakistan, this crop is the major crop of spring and autumn seasons grown over 0.9 million hectares every year. The yield of maize crop in Pakistan is very low as compared with other maize grown countries (Anonymous, 2017). Various factors are responsible for this low yield and one of them is the maize stem borer, Chilo partellus Swinhoe (Lepidoptera: Pyralidae) which is very destructive insect pest of many countries from Africa and Asia including Pakistan (Nabeel et al., 2018). Among the insect pests, C. partellus, has the potential to cause upto 75\% crop losses (Kumar and Alam, 2017; Songa et al., 2001).

This insect pest has great potential to cause economic damage to the maize crop and has the ability to cause $100 \%$ damage at seedling stage of maize crop (Ali and Issa, 2019). At the milking stage, this pest can decrease the grain yield upto $81 \%$ (Kumar et al., 2018). The main reasons for this high damage to the maize crop is the lack of proper resistance varieties, which perform significant role in controlling and feeding behavior of the pest (Murenga et al., 2018).

The female lays eggs on the tender leaves and newly hatched larvae feed on these leave and later on the larvae bores into the midrib, stalk and feed inside maize stem. This feeding behavior prevents it from the attack of natural enemies and insecticides (Siddalingappa et al., 2010). Various control measures have been used to manage this pest including cultural control (Dhaliwal et al., 2017) and biological control methods (Saeed et al., 2014).

Chemical control is a quick way to control insect pests (Kumar and Alam, 2017; Malik et al., 2015). These chemical insecticides have various types of formulations like granular formulations. Insecticides mostly recommended as soil and/or whorl application after 25 and 45 days of sowing of maize crop (Khan and Yamin, 2004). Moreover, foliar application of insecticides is effective as compared to granular formulation (Sidar et al., 2017). The insect pest can also be controlled by the whorl application of insecticides (granular and foliar) in liquid formulations (Gunewardena and Madugalla, 2012).

All species of C. partellus have well developed cellular and humeral resistance structure in insect body that prevents them from the chemical, harsh conditions and disease causing agents. Insect immune systems eradicate the invaded tissues when identified (Fatima et al., 2013). Insect cellular immune structure consists of haemocytes which travel in blood of insect and usually interact with the tissues of insect body, whereas humeral immune reaction comprises of soluble molecules production (Strand, 2008).

Insect haemocytes play a significant role in the physical structure of the organisms. Haemocyte structure and function primarily have been considered in genetic or physical structure of insect models as well as the fruit fly (Ulvila et al., 2011). Haemocytes are generated from the embryonic medium mesodermal tissues and are separated into various types through embryogenesis (Fatima et al., 2013; Klowden, 2013). Being involved in phagocytosis and encapsulation, haemocyte forms the cellular Immune system of many arthropods (Gupta, 2019; Salt, 1970). Haemolymph of insects contains number of circulating cells ranging from 25000-100,000 per cubic mm but this range of cells is much more less than the large insects (Fatima et al., 2016).

When a chemical is applied on insect, first of all it affects the defense system of insect pests by altering its haemocytes number. Different insects have shown different effects on circulating cell types and shapes when different insecticides were applied on them (Qamar and Jamal, 2009). Insects use the immunity system to counteract Infections by a diverse array of pathogens including the identification of pathogens connected with molecular pattern (Janeway, 1989). Even when insects encounter a pesticide particle, they trigger their immune system and hence the pesticide, which is capable to suppress the immune system efficiently, is considered good. Therefore, the present study was conducted to evaluate the efficiency of new chemistry insecticides on the total and differential haemocytes counts of maize stem borer and to evaluate the abnormalities in the haemocytes of maize stem borer.

\section{MATERIALS AND METHODS}

Insect culture: In the present study, the already established culture of maize stem borer (Chilo partellus) was used. The rearing method of stem borer included 10 larva per jar which was kept with newly cut the maize stem for food. The piece of maize stem was put into the 
jar and then was tight head of jar with muslin cloth. The food of larvae was changed after 2 days' interval as per need, larvae were observed for pupation while changing food pupae were collected and kept in emergence jar. Pupae were observed on daily basis for emergence.

Adults on emergence were shifted to oviposition jars. Ovipositor jars were lined with white paper at bottom and with leaves of maize plant at sides. Leaves were placed for egg lying by adult moths. Leaves were changed on daily basis. Eggs were collected by cutting leaves and white paper into small pieces and were shifted in hatching jar. After 4-6 days first instars, larvae hatched from eggs and were shifted to rearing jars with food. The cycle goes on for mass culturing. Insect culture was maintained at $25 \pm 2{ }^{\circ} \mathrm{C}$ with $60 \pm 5 \%$ relative humidity.

Insecticides: In the present study, four new chemistry insecticides were used to evaluate the haemocytological activity of Chilo partellus. $\mathrm{LC}_{50}$ and $\mathrm{LC}_{60}$ of each insecticide were calculated using bioassay. Following new chemistry insecticide were used for the experiment. Radient 120 SC (Spinetcoram)

Chlorfenapyr 360 SC (Chlorfenapyr)

Belt 48 S C (Flubendiamide)

Match 50 EC (Lufenuron)

Bioassays: To calculate the lethal concentration values, natural diet of maize stem was used by diet incorporation bioassay method. Five concentrations of each insecticide were mixed in $10 \mathrm{ml}$ of water in five separate beakers. Then freshly prepared diet was poured in each beaker making a total weight of $100 \mathrm{ml}$ (10 ml water: $90 \mathrm{ml} \mathrm{diet).} \mathrm{In} \mathrm{the} \mathrm{control} \mathrm{beaker,} \mathrm{no}$ insecticides were mixed but just the distilled water. In the diet preparation, antibiotic mixture was not used when the diet was prepared for bioassay and a reduction of 10 percent insecticides mixture can easily solidify the natural diet mixture.

Each concentration was fed to 30 insects larvae in the six whole petri-plates and data were taken after $24 \mathrm{hr} 48 \mathrm{hr}$ And 72 hr. Mortality for each concentration were observed and a value of lethal concentration were calculated by using $\mathrm{R}$ statistical program. Similar, procedure was used for all other insecticides on $3^{\text {rd }}$ and $5^{\text {th }}$ instars larvae. $\mathrm{LC}_{50}$ and $\mathrm{LC}_{60}$ were calculated out using the $\mathrm{R}$ version 2.9 .0 of all the four insecticides against selected instar larvae.

Insecticides application: The insecticide was applied on individual insect with the help of micro applicator at the rate of 3 ul per larvae. Third and fifth larval instars were chosen for insecticide application and haemocytes studies. Effect of these insecticides was observed immediately after application, after 30 minutes and after 60 minutes in terms of abnormalities in total haemocyte count and differential haemocyte count.

Preparation of slides: The haemolymph of Chilo Partellus larvae were taken on a microscopic slide with help of insulin syringe from the abdominal of larvae. A smear was made by drawing a second slide across the first one. This smear was air dried for four minutes and stained properly with Wright's stain by following procedure.

a) Air dried the blood film for four minutes

b) Dip the slide having blood smear in methyl alcohol for 5-7 minutes

c) Air dried the film

d) Immerse the dried film in the Wright's stain for 15 minutes

e) Wash the slides with the distilled water of pH 6.8

f) Air dried the slides

g) Neutralize the haemocyte content in freshly prepared buffer solution of $\mathrm{pH} 6.6$ for 15 minutes

The slides were mounted with the Canada balsam and put a glass cover slip on the slide to observe blood types under microscope.

Differential haemocytes count (DHC): After making the slides, different types of haemocytes were identified within the hemolymph of Chilo partellus. Differential haemocytes counting were done with the help of telecounter under Phase Contrast microscope 10X. A minimum of 200 cells were counted each time and the percentage of various classes were calculated.

Total haemocytes count (THC): Haemocytometer were used for the counting of total haemocytes. Standard sampling of the haemolymph was carried out with white blood cell diluting pipette. Haemolymph for the abdominal legs were collected on a glass slide and then quickly drawn into white blood cell diluting pipette upto mark 0.5. And then diluted 20 times with toissin $(\mathrm{NaCl}=$ $1.0 \mathrm{gm}, \mathrm{Na} 2 \mathrm{SO} 4=8.0 \mathrm{gm}$, neutral glycerine $=30 \mathrm{ml}$, Methyl violet $=0.025 \mathrm{gm}$ and distilled water $=160 \mathrm{ml}$ ) and Thoma white blood cell diluting pipette was filled upto mark This solution was properly stained with staining shaker for 5 minutes it prevents the blood to coagulate.

Three initial drop of haemolymph mixture were placed near the edge of the coverslip of the Neubauer 
haemocytometer. The counting chamber was filled automatically by capillary action. Haemocytometer will leave for 5 minutes so that the blood cell could settle down and then observed the haemocytes under phase contract microscope 10X. The four corners square of both chamber of haemocytometer were counted under low power followed by high power of microscope focusing the counting chamber.

Cells of each group of 16 squares, touching bordering the bottom left hand side and the central line were counted. Cells touching the central line in the top and right hand side will not include in the count. Total haemocytes counting (THC) were done following the formula described by Jones (1962). Actual number of cell per cubic $\mathrm{mm}=$ Average number of cell counted per square millimeter $\mathrm{x}$ depth $\mathrm{x}$ dilution per square millimeter.

Statistical analysis: The treatment (insecticide doses) were replicated four times using CRD (Completely
Randomized Design) and for each treatment, 30 insects were used with five replications. Six individuals were selected randomly and taking average as one reading for each of the replicate.

\section{RESULTS AND DISCUSSION}

Toxicity bioassays: The current study was carried out to evaluate the toxicity of four new chemistry insecticides and its effect on haemocytological activities of the $3^{\text {rd }}$ and $5^{\text {th }}$ instar larvae of $C$. partellus. The $\mathrm{LC}_{50}$ andLC 60 values for Radiant against $3^{\text {rd }}$ instar of $C$. partellus after 24 hours were $12.2 \mathrm{ppm}$ and $24.2 \mathrm{ppm}$ respectively (Table 1), while the same value after 72 hours was 7.24 ppm and $14.84 \mathrm{ppm}$ respectively. For the $5^{\text {th }}$ larval instar of $C$. partellus, the $\mathrm{LC}_{50}$ and $\mathrm{LC}_{60}$ values were calculated as $44.2 \mathrm{ppm}$ and $61.9 \mathrm{ppm}$ respectively (Table 2) after 24 hours and $\mathrm{LC}_{50}$ and $\mathrm{LC}_{60}$ values for radiant against $5^{\text {th }}$ larval instar of $C$. partellus were calculated as $23.94 \mathrm{ppm}$ and $43.51 \mathrm{ppm}$ respectively after 72 hours.

Table 1: $\mathrm{LC}_{50}$ and $\mathrm{LC}_{60}$ values of different new chemistry insecticides for $3^{\text {rd }}$ instar larvae of Chilo partellus after 24,48 and $72 \mathrm{~h}$.

\begin{tabular}{|c|c|c|c|c|c|}
\hline Insecticides & $\mathrm{N}$ & Time (h) & $\begin{array}{c}\mathrm{LC}_{50}(\mathrm{ppm}) \\
(95 \% \mathrm{CL})\end{array}$ & $\begin{array}{c}\mathrm{LC}_{60}(\mathrm{ppm}) \\
(95 \% \mathrm{CL})\end{array}$ & Slope $( \pm S E)$ \\
\hline \multirow{3}{*}{ Radiant } & 30 & 24 & $\begin{array}{c}12.2 \\
(3.19-22.81)\end{array}$ & $\begin{array}{c}24.2 \\
(12.1-36.27)\end{array}$ & $1.47( \pm 0.106)$ \\
\hline & 30 & 48 & $\begin{array}{c}10.14 \\
(2.11-16.1)\end{array}$ & $\begin{array}{c}18.24 \\
(9.12-30.17)\end{array}$ & $1.97( \pm 0.100)$ \\
\hline & 30 & 72 & $\begin{array}{c}7.24 \\
(2.2-13.2)\end{array}$ & $\begin{array}{c}14.84 \\
(4.53-24.26)\end{array}$ & $1.46( \pm 0.112)$ \\
\hline \multirow{3}{*}{ Chlorfenapyr } & 30 & 24 & $\begin{array}{c}8.21 \\
(3.52-16.27)\end{array}$ & $\begin{array}{c}16.35 \\
(7.48-27.29)\end{array}$ & $1.90( \pm 0.093)$ \\
\hline & 30 & 48 & $\begin{array}{c}6.19 \\
(1.48-14.24)\end{array}$ & $\begin{array}{c}12.57 \\
(5.37-21.4)\end{array}$ & $1.67( \pm 0.108)$ \\
\hline & 30 & 72 & $\begin{array}{c}4.21 \\
(1.08-10.17)\end{array}$ & $\begin{array}{c}7.31 \\
(3.17-12.22)\end{array}$ & $1.86( \pm 0.118)$ \\
\hline \multirow{3}{*}{ Belt } & 30 & 24 & $\begin{array}{c}3.4 \\
(0.99-5.89)\end{array}$ & $\begin{array}{c}7.14 \\
(3.9-13.2)\end{array}$ & $1.77( \pm 0.106)$ \\
\hline & 30 & 48 & $\begin{array}{c}1.99 \\
(0.049-4.28)\end{array}$ & $\begin{array}{c}3.23 \\
(1.002-7.27)\end{array}$ & $1.79( \pm 0.101)$ \\
\hline & 30 & 72 & $\begin{array}{c}0.152 \\
(0.011-2.23)\end{array}$ & $\begin{array}{c}1.78 \\
(0.079-4.87)\end{array}$ & $1.94( \pm 0.112)$ \\
\hline \multirow{3}{*}{ Match } & 30 & 24 & $\begin{array}{c}11.21 \\
(5.5-21.27)\end{array}$ & $\begin{array}{c}21.2 \\
(12.1-30.9)\end{array}$ & $1.99( \pm 0.093)$ \\
\hline & 30 & 48 & $\begin{array}{c}7.94 \\
(2.54-18.25)\end{array}$ & $\begin{array}{c}14.73 \\
(6.64-24.53)\end{array}$ & $1.37( \pm 0.108)$ \\
\hline & 30 & 72 & $\begin{array}{c}3.126 \\
(0.948-10.1)\end{array}$ & $\begin{array}{c}8.65 \\
(3.27-19.22)\end{array}$ & $1.93( \pm 0.118)$ \\
\hline
\end{tabular}


Chlorfenpyr application against the $3^{\text {rd }}$ larval instar showed higher $\mathrm{LC}_{50}$ and $\mathrm{LC}_{60}$ values as $8.21 \mathrm{ppm}$ and $16.35 \mathrm{ppm}$ (Table 1 ) after 24 hours, while after 72 hours these values decreased as $4.21 \mathrm{ppm}$ and $7.31 \mathrm{ppm}$ for $\mathrm{LC}_{50}$ and $\mathrm{LC}_{60}$ respectively. Similarly, the $\mathrm{LC}_{50}$ and $\mathrm{LC}_{60}$ values for $5^{\text {th }}$ larval instar of $C$. partellus were $56.4 \mathrm{ppm}$ and $73.51 \mathrm{ppm}$ respectively (Table 2). After 72 hours, $\mathrm{LC}_{50}$ and $\mathrm{LC}_{60}$ were calculated as $32.91 \mathrm{ppm}$ and 52.71 ppm respectively.

Results revealed that among the four new chemistry insecticides used in the current study, Belt was much more effective as compared to others. The $\mathrm{LC}_{50}$ and $\mathrm{LC}_{60}$ values for $3^{\text {rd }}$ larval instar were calculated as $3.4 \mathrm{ppm}$ and $7.14 \mathrm{ppm}$ after 24 hours (Table 1), with respect to time decrease was observed in the $\mathrm{LC}_{50}$ and $\mathrm{LC}_{60}$ values after 72 hours as $0.152 \mathrm{ppm}$ and $1.78 \mathrm{ppm}$ respectively. For $5^{\text {th }}$ larval instar the $\mathrm{LC}_{50}$ and $\mathrm{LC}_{60}$ values were calculated as $21.2 \mathrm{ppm}$ and $36.7 \mathrm{ppm}$ after 24 hours (Table 2) and after 72 hours these values were observed as $8.25 \mathrm{ppm}$ and $14.5 \mathrm{ppm}$ respectively.

Table 2: $\mathrm{LC}_{50}$ and $\mathrm{LC}_{60}$ values of different new chemistry insecticides for $5^{\text {th }}$ instar larvae of Chilo partellus after 24,48 and $72 \mathrm{~h}$.

\begin{tabular}{cccccc}
\hline Insecticides & $\mathrm{N}$ & Time $(\mathrm{h})$ & $\mathrm{LC}_{50}(\mathrm{ppm})$ & $\mathrm{LC}_{60}(\mathrm{ppm})$ & Slope $\pm \mathrm{SE})$ \\
\hline \multirow{3}{*}{ Radiant } & 30 & 24 & 44.2 & 61.9 & $1.91( \pm 0.127)$ \\
& 30 & 48 & 32.7 & 52.64 & $1.78( \pm 0.140)$ \\
& 30 & 72 & 23.94 & 43.51 & $1.62( \pm 0.172)$ \\
Chlorfenapyr & 30 & 24 & 56.4 & 73.51 & $1.94( \pm 0.093)$ \\
& 30 & 48 & 42.29 & 63.17 & $1.87( \pm 0.128)$ \\
& 30 & 72 & 32.91 & 52.71 & $1.97( \pm 0.121)$ \\
Belt & 30 & 24 & 21.2 & 36.7 & $1.81( \pm 0.096)$ \\
& 30 & 48 & 16.29 & 25.93 & $1.90( \pm 0.124)$ \\
& 30 & 72 & 8.25 & 14.5 & $1.84( \pm 0.108)$ \\
Match & 30 & 24 & 39.5 & 59.7 & $1.88( \pm 0.093)$ \\
& 30 & 48 & 24.14 & 41.53 & $1.67( \pm 0.121)$ \\
& 30 & 72 & 18.26 & 33.45 & $1.73( \pm 0.127)$ \\
\hline
\end{tabular}

Match was also used against the $3^{\text {rd }}$ and $5^{\text {th }}$ larval instar of C. partellus in the present study. Results of the $3^{\text {rd }}$ larval instar were observed as $\mathrm{LC}_{50}$ of $11.21 \mathrm{ppm}$ and $\mathrm{LC}_{60}$ of $21.2 \mathrm{ppm}$ after 24 hours (Table 1), while after 72 hours the results were as $\mathrm{LC}_{50}$ of $3.126 \mathrm{ppm}$ and $\mathrm{LC}_{60}$ of $8.65 \mathrm{ppm}$ respectively. The results for $5^{\text {th }}$ larval instar, $\mathrm{LC}_{50}$ of $39.5 \mathrm{ppm}$ and $\mathrm{LC}_{60}$ of $59.7 \mathrm{ppm}$ after 24 hours and $\mathrm{LC}_{50}$ of $18.26 \mathrm{ppm}$ and $\mathrm{LC}_{60}$ of $33.45 \mathrm{ppm}$ after 72 hours (Table 2) were observed respectively.

The above results showed that Belt was more effective against the $3^{\text {rd }}$ and $5^{\text {th }}$ larval instars of $C$. partellus on the basis of their low $\mathrm{LC}_{50}$ and $\mathrm{LC}_{60}$ values as compared to the other tested three insecticides. The reason for this low LC values might be that Belt is toxic to borers while other insecticides are effective against the sucking insects.

Observed types of haemocytes: On the basis of their essential characteristics, following six different haemocytes were observed in the haemolymph of $C$. partellus.
Prohaemocytes (PR)

Plasmatocytes (PL)

Spherulocytes (SP)

Granulocytes (GR)

Cystocytes (CO)

Oenocytoids (OE)

Total and differential haemocytes count for $3^{\text {rd }}$ larval instar of $\boldsymbol{C}$. partellus: after the application of all four insecticides on the $3^{\text {rd }}$ instar larvae of $c$. partellus, the total haemocytes and differential haemocytes were observed and calculated as prescribed earlier.

Total and differential haemocytes counts in untreated: in the current study, the mean counts of total haemocytes observed were about 72155 blood cells $/ \mathrm{mm}^{3}$ in the $3^{\text {rd }}$ larval instar of c. partellus. The percent of different haemocytes in untreated $3^{\text {rd }}$ instar larvae of c. partellus were observed as prohaemocytes $(43.23 \%)$, spherulocytes $(31.388 \%)$, plasmatocyted (17.86\%), granulocytes $(9.12 \%)$ and cystocytes (4.22\%). 
Total haemocytes and differential haemocytes for Radiant at $\mathbf{L C}_{\mathbf{5 0}}$ : Table 3 shows the total haemocytes count of the $3^{\text {rd }}$ larval instar of $C$. partellus when treated with Radiant. The finding showed that the total haemocytes counts increased (75841 cells $/ \mathrm{mm}^{3}$ ) from the normal (72155 cells $/ \mathrm{mm}^{3}$ ) just after the application of insecticides radiant, after 30 minutes the total haemocytes count decreases $\left(71049.5\right.$ cells $\left./ \mathrm{mm}^{3}\right)$, while after 60 minutes, the total Haemocytes count again increases $\left(79248 \mathrm{cell} / \mathrm{mm}^{3}\right)$. The current findings are in agreement with Fatima et al. (2013) and Fareed (2001) who noted that the total haemocytes increased immediately after the application of the chemical, then decreases and again after one hour the haemocytes increases.
Table 4 illustrates the differential haemocytes count observed in the 3rd larval instar of $C$. partellus. Differential haemocytes counts, the percent of plasmocytes have increase from $17.86 \%$ to $28 \%$, however the percent of spherulocytes, granulocytes, prohaemocytes and cystocytes have decreases from the untreated value as $30 \%, 8 \%, 31 \%$ and $3 \%$ respectively. These results are in favor to the results of Alhariri et al. (2002), Fatima et al. (2013) and Fareed (2001) who stated that the plasmocytes increases with the application of insecticides, however our results are dissimilar to Rizwan-ul-Haq et al. (2005) who found that after the application of imidacloprid the percent of plasmocyted decreases from its normal untreated percentage.

Table 3: Total haemocytes counts of $C$. partellus larvae affected by Radiant.

\begin{tabular}{ccccc}
\hline \multirow{2}{*}{ Radiant Conc. } & \multicolumn{3}{c}{ LC $_{50}$} & LC $_{60}$ \\
\cline { 2 - 5 } & $3^{\text {rd }}$ instar & $5^{\text {th }}$ instar & $3^{\text {rd }}$ instar & $5^{\text {th }}$ instar \\
\hline 0 Minutes & 75841 & 22541.5 & 78548.5 & 26485 \\
30 Minutes & 71049.5 & 18543 & 71694 & 19620 \\
60 Minutes & 79248 & 24567 & 80215 & 27940 \\
\hline
\end{tabular}

Table 4: Differential haemocytes counts of $C$. partellus larvae affected by Radiant.

\begin{tabular}{ccccc}
\hline \multirow{2}{*}{ Radiant Conc. } & \multicolumn{3}{c}{$\mathrm{LC}_{50}$} & $\mathrm{LC}_{60}$ \\
\cline { 2 - 5 } & $3^{\text {rd }}$ instar & $5^{\text {th }}$ instar & $3^{\text {rd }}$ instar & $5^{\text {th }}$ instar \\
\hline PR\% & 31 & 29 & 33 & 30.5 \\
$\mathrm{PL} \%$ & 28 & 31.25 & 26 & 27.75 \\
$\mathrm{SP} \%$ & 30 & 26 & 39 & 28.5 \\
$\mathrm{GR} \%$ & 8 & 4 & 6.75 & 2 \\
$\mathrm{CO} \%$ & 3 & 3.75 & 2.25 & 1.25 \\
$\mathrm{OE} \%$ & 0 & 6 & 0 & 4 \\
\hline
\end{tabular}

Total haemocytes and differential haemocytes for Radiant at $\mathbf{L C}_{\mathbf{6 0}}$ : After the application of Radiant insecticide, the total haemocytes count immediately increase $\left(78548.5\right.$ cells $\left./ \mathrm{mm}^{3}\right)$ as compared to normal ( 71155 cells $/ \mathrm{mm}^{3}$ ), however after 30 minutes to decreases to $\left(71694\right.$ cells $\left./ \mathrm{mm}^{3}\right)$ and after 60 minutes of interval, the total haemocytes count again increases as (80215 cell $/ \mathrm{mm}^{3}$ ) (Table 3). Percent plasmotcytes increase from untreated to $26 \%$, while on $3^{\text {rd }}$ larval instar of $C$. partellus the spherulocytes, granulocytes, prohaemocytes and cystocytes also fluctuated from the untreated as 39\%, $6.75 \%, 33 \%$ and $2.25 \%$ respectively (Table 4 ).

Total haemocytes and differential haemocytes for Chlorfenapyr at $\mathbf{L C}_{\mathbf{5 0}}$ : Table 5 shows the total haemocytes count of the $3^{\text {rd }}$ larval instar of $C$. partellus when treated with chlorfenpyr. The finding show that the total haemocytes counts increased (82640 cells $/ \mathrm{mm}^{3}$ ) from the normal (72155 cells $/ \mathrm{mm}^{3}$ ) just after the application of insecticides Chlorfenapyr, after 30 minutes the total haemocytes count decreases (72010 cells $/ \mathrm{mm}^{3}$ ), while after 60 minutes, the total haemocytes count again increases (86350 cell $\left./ \mathrm{mm}^{3}\right)$. The current findings are in agreement with Abbas et al. (2008) who used Sevin and Match respectively on Papilio demoleus and found that the total haemocytes increased immediately after the application of the chemical, then decreased and again after one hour the haemocytes increased. 
Table 6 illustrates the differential haemocytes count observed in the $3^{\text {rd }}$ larval instar of $C$. partellus. Differential haemocytes counts, the percent of plasmocytes have increased from $17.86 \%$ to $30.25 \%$, however the percent of spherulocytes, granulocytes, prohaemocytes and cystocytes have decreased from the untreated value as $26.5 \%, 6.5 \%$, $32.75 \%$ and $1 \%$ respectively. These results are in favor to the results of Abbas et al. (2008) and Fareed (2001) who stated that the plasmocytes increases with the application of insecticides.

Total haemocytes and differential haemocytes for
Chlorfenpyr at $\mathbf{L C}_{\mathbf{6 0}}$ : After the application of Chlorfenpyr insecticide, the total haemocytes count immediately increased $\left(80920.75\right.$ cells $\left./ \mathrm{mm}^{3}\right)$ as compared to normal $\left(71255\right.$ cells $\left./ \mathrm{mm}^{3}\right)$, however after 30 minutes decreased to $\left(71155\right.$ cells $\left./ \mathrm{mm}^{3}\right)$ and after 60 minutes of interval, the total haemocytes count again increased as $\left(84100\right.$ cell $\left./ \mathrm{mm}^{3}\right)$ (Table 5). Percent plasmotcytes increased from untreated to $36 \%$, while the spherulocytes, granulocytes, prohaemocytes and cystocytes also fluctuated from the untreated as $23.5 \%$, $5.5 \%, 29 \%$ and $1.5 \%$ respectively (Table 6).

Table 5: Total Haemocytes counts of $C$. partellus larvae affected by Chlorfenapyr.

\begin{tabular}{ccccc}
\hline \multirow{2}{*}{ Conc. } & \multicolumn{3}{c}{ LC $_{50}$} & \multicolumn{2}{c}{ LC $_{60}$} \\
\cline { 2 - 5 } & $3^{\text {rd }}$ instar & $5^{\text {th }}$ instar & $3^{\text {rd }}$ instar & $5^{\text {th }}$ instar \\
\hline 0 Minutes & 82640 & 22435 & 80920.75 & 23120 \\
30 Minutes & 72010 & 18300 & 71155 & 20100 \\
60 Minutes & 86350 & 24595 & 84100 & 25600 \\
\hline
\end{tabular}

Table 6: Differential Haemocytes counts of $C$. partellus larvae affected by Chlorfenapyr.

\begin{tabular}{|c|c|c|c|c|}
\hline \multirow{2}{*}{ Conc. } & \multicolumn{2}{|c|}{$\mathrm{LC}_{50}$} & \multicolumn{2}{|c|}{$\mathrm{LC}_{60}$} \\
\hline & $3^{\text {rd }}$ instar & $5^{\text {th }}$ instar & $3^{\text {rd }}$ instar & $5^{\text {th }}$ instar \\
\hline PR\% & 32.75 & 30 & 29 & 27 \\
\hline PL\% & 30.25 & 31.5 & 36 & 44 \\
\hline $\mathrm{SP} \%$ & 26.5 & 19 & 23.5 & 17 \\
\hline GR\% & 6.5 & 1.75 & 5.5 & 1.25 \\
\hline $\mathrm{CO} \%$ & 1 & 0.5 & 1.5 & 0.75 \\
\hline OE\% & 0 & 12.25 & 0 & 11 \\
\hline
\end{tabular}

Total haemocytes and differential haemocytes for Belt at $\mathbf{L C}_{\mathbf{5 0}}$ : Table 7 shows the total haemocytes count of the $3^{\text {rd }}$ larval instar of $C$. partellus when treated with Belt. The finding showed that the total haemocytes counts increased $\left(82500\right.$ cells $\left./ \mathrm{mm}^{3}\right)$ from the normal (72155 cells $/ \mathrm{mm}^{3}$ ) just after the application of insecticides Belt, after 30 minutes the total haemocytes count was $\left(70200\right.$ cells $\left./ \mathrm{mm}^{3}\right)$, while after 60 minutes, the total haemocytes count again increased (84550 cell $/ \mathrm{mm}^{3}$ ). The current findings are in agreement with those of Fatima et al. (2013); Rajak et al. (2014) and Fareed (2001) who noted that the total haemocytes increased immediately after the application of the chemical, then decreased and again after one hour the haemocytes increases.

Table 8 shows the differential haemocytes count observed in the $3^{\text {rd }}$ larval instar of $C$. partellus.
Differential haemocytes counts, the percent of plasmocytes have increased from $17.86 \%$ to $31 \%$, however the percent of spherulocytes, granulocytes, prohaemocytes and cystocytes have decreased from the untreated value as $29 \%, 9 \%, 28 \%$ and $4 \%$ respectively. These results are in agreement with the results of Alhariri et al. (2002) and Fatima et al. (2014); Fatima et al. (2016) who stated that the plasmocytes increased with the application of insecticides, however our results are dissimilar to Kalyani and Holihosur (2015) who found that after the application of chemical the percent of plasmocytes decreased from its normal untreated percentage.

Total haemocytes and differential haemocytes for Belt at $\mathbf{L C}_{\mathbf{6 0}}$ : After the application of Belt insecticide, the total haemocytes count immediately increased $(87200$ cells $\left./ \mathrm{mm}^{3}\right)$ as compared to normal $\left(71255\right.$ cells $\left./ \mathrm{mm}^{3}\right)$, 
however after 30 minutes decreased to $(71270$ cells $/ \mathrm{mm}^{3}$ ) and after 60 minutes of interval, the total haemocytes count again increased as $\left(89640 \mathrm{cell} / \mathrm{mm}^{3}\right)$ (Table 7). Percent plasmotcytes increased from untreated to $36 \%$, while the spherulocytes, granulocytes, prohaemocytes and cystocytes also fluctuated from the untreated as $32.5 \%, 8.5 \%, 17.25 \%$ and $4.75 \%$ respectively (Table 8).

Table 7: Total haemocytes counts of $C$. partellus larvae affected by Belt.

\begin{tabular}{ccccc}
\hline \multirow{2}{*}{ Conc. } & \multicolumn{3}{c}{ LC $_{50}$} & LC $_{60}$ \\
\cline { 2 - 5 } & $3^{\text {rd }}$ instar & $5^{\text {th }}$ instar & $3^{\text {rd }}$ instar & $5^{\text {th }}$ instar \\
\hline 0 Minutes & 82500 & 19500 & 87200 & 21535 \\
30 Minutes & 70200 & 18965 & 71270 & 18532.5 \\
6 Minutes & 84550 & 21055 & 89640 & 23540 \\
\hline
\end{tabular}

Table 8: Differential Haemocytes counts of $C$. partellus larvae affected by Belt.

\begin{tabular}{ccccc}
\hline \multirow{2}{*}{ Conc. } & \multicolumn{3}{c}{$\mathrm{LC}_{50}$} & $\mathrm{LC}_{60}$ \\
\cline { 2 - 5 } & $3^{\text {rd }}$ instar & $5^{\text {th }}$ instar & $3^{\text {rd }}$ instar & $5^{\text {th }}$ instar \\
\hline $\mathrm{PR} \%$ & 28 & 35.5 & 17.25 & 23 \\
$\mathrm{PL} \%$ & 31 & 32.25 & 36 & 38 \\
$\mathrm{SP} \%$ & 29 & 25 & 32.5 & 28.5 \\
$\mathrm{GR} \%$ & 9 & 5.5 & 8.5 & 6.5 \\
$\mathrm{CO} \%$ & 4 & 3 & 4.75 & 4 \\
$\mathrm{OE} \%$ & 0 & 13.75 & 0 & 12 \\
\hline
\end{tabular}

Total haemocytes and differential haemocytes for Match at $\mathbf{L C}_{\mathbf{5 0}}$ : Table 9 shows the total haemocytes count of the $3^{\text {rd }}$ larval instar of $C$. partellus when treated with match. The finding showed that the total haemocytes counts increased (78375 cells $/ \mathrm{mm}^{3}$ ) from the normal (72155 cells $/ \mathrm{mm}^{3}$ ) just after the application of insecticides Match, after 30 minutes the total haemocytes count decreased $\left(72080\right.$ cells $\left./ \mathrm{mm}^{3}\right)$, while after 60 minutes, the total haemocytes count again increased $\left(86500 \mathrm{cell} / \mathrm{mm}^{3}\right)$. The current findings are in agreement with Abbas et al. (2008) who used Match respectively on Papilio demoleus and found that the total haemocytes increased immediately after the application of the chemical and then decreased and again after one hour the haemocytes increased. Table 10 illustrates the differential haemocytes count observed in the $3^{\text {rd }}$ larval instar of $C$. partellus. Differential Haemocytes counts, the percent of plasmocytes have increased from $17.86 \%$ to $28 \%$, however the percent of spherulocytes, granulocytes, prohaemocytes and cystocytes have decreased from the untreated value as $33 \%, 11 \%, 27 \%$ and $5 \%$ respectively. These results are in line with those of Abbas et al. (2008) and Fareed (2001) who stated that the plasmocytes increased with the application of insecticides.

Table 9: Total Haemocytes counts of C. partellus larvae affected by Match.

\begin{tabular}{ccccc}
\hline \multirow{2}{*}{ Conc. } & \multicolumn{3}{c}{ LC $_{50}$} & \multicolumn{2}{c}{ LC $_{60}$} \\
\cline { 2 - 5 } & $3^{\text {rd }}$ instar & $5^{\text {th }}$ instar & $5^{\text {th }}$ instar & 16565 \\
\hline 0 Minutes & 78375 & 15600 & 87500 & 15600 \\
30 Minutes & 72080 & 12245 & 72190 & 23855 \\
60 Minutes & 86500 & 19865 & 99800 & \\
\hline
\end{tabular}

Total haemocytes and differential haemocytes for Match at $\mathbf{L C}_{\mathbf{6 0}}$ : After the application of match insecticide, the total haemocytes count immediately increased (87500 cells $/ \mathrm{mm}^{3}$ ) as compared to normal (72155 cells $/ \mathrm{mm}^{3}$ ), however after 30 minutes decreased to (72190 cells $\left./ \mathrm{mm}^{3}\right)$ and after 60 minutes of interval, the total haemocytes count again increased as $(99800$ cell $/ \mathrm{mm}^{3}$ ) (Table 9). Percent plasmotcytes increased 
from untreated to $33 \%$, while the spherulocytes, granulocytes, prohaemocytes and cystocytes also fluctuated from the untreated as 31\%, 14\%, 23\% and 4 $\%$ respectively (Table 10 ).

Table 10 Differential Haemocytes counts of $C$. partellus larvae affected by Match.

\begin{tabular}{ccccc}
\hline \multirow{2}{*}{ Conc. } & \multicolumn{2}{c}{$\mathrm{LC}_{50}$} & \multicolumn{3}{c}{$\mathrm{LC}_{60}$} \\
\cline { 2 - 5 } & $3^{\text {rd }}$ instar & $5^{\text {th }}$ instar & $3^{\text {rd }}$ instar & $5^{\text {th }}$ instar \\
\hline PR\% & 27 & 31 & 23 & 29 \\
PL\% & 28 & 29 & 33 & 32 \\
SP\% & 33 & 34 & 31 & 30 \\
GR\% & 11 & 9.25 & 14 & 11.75 \\
CO\% & 5 & 6.75 & 4 & 5.25 \\
OE\% & 0 & 14 & 0 & 10 \\
\hline
\end{tabular}

\section{Author's contribution}

SA, MT and AG designed the study; SA, RA and SK executed the experimental work; AG and MI analyzed the data; MT and MI supervised the work; SA wrote the manuscript; MT, AG and SK edited the manuscript and all the authors approved the write-up.

\section{Conflict of interest}

The authors declare no conflict of interest.

\section{REFERENCES}

Abbas, I., Fitriana, N., Nakano, S., Nakamura, K., 2008. Duration of immature stages of eleven swallowtail butterflies (Lepidoptera: Papilionidae) in West Sumatra, Indonesia. Far Eastern Entomologist 182, 1-9.

Alhariri, M., Nighat, P., Ahmad, M., Suhail, A., 2002. Insecticidal mortality, foraging, behavior and pollination role of honey bee (Apis mellifera L.) on sarsoon (Brassica compestris L.) crop. International Journal of Agriculture Biology 2, 332-333.

Ali, A., Issa, A.B., 2019. Economic impact of maize stem borer (Chilo partellus) attack on livelihood of maize farmers in Pakistan. Asian Journal of Agriculture and Biology 7, 311-319.

Anonymous, 2017. Pakistan Agriculture Research Council, Government of Sindh, Agriculture Department.

Chouraddi, M., Mallapur, C.P., Balikai, R.A., 2016. Evaluation of biopesticides/bio-control agents against maize stem borers. Annuals of Entomology 34, 15-21.

Dhaliwal, A.K., Brar, D.S., Jindal, J., 2017. Evaluation of different IPM components for the management of maize stem borer, Chilo partellus (Swinhoe) in
Kharif maize. Journal of Entomological Research $41,287-291$.

Fareed, T., 2001. Toxicity of some insecticides on the haemocytes of spotted bollworm, Earias spp., and American bollworm, Helicoverpa armigera of cotton. University of Agriculture, Faisalabad, Pakistan.

Fatima, M., Tariq, M., Gulzar, A., 2013. Effect of flubendiamide and spirotetramat on the haemocytes of American bollworm, Helicoverpa armigera (Lepidoptera: Noctuidae). Pakistan Entomologist 35, 129-134.

Fatima, M., Tariq, M., Gulzar, A., 2014. Effect of triflumuron and diafenthuron on the haemocytes of American bollworm, Helicoverpa armigera (Lepidoptera: Noctuidae). Pakistan Entomologist 36, 51-56.

Fatima, M., Tariq, M., Tariq, K., Naz, G., Anwar, Z., Gulzar, A., Ali, A., Khan, A.A., Khursheed, I., Shah, J.A., 2016. Effect of Thiacloprid and Imidacloprid on the Haemocytes of American Bollworm, Helicoverpa armigera. American-Eurasian Journal of Toxicological Sciences 8, 139-143.

Gunewardena, K.N.C., Madugalla, S.R.K., 2012. Efficacy of selected granular insecticides for the control of maize-stem borer (Chilo partellus)(Lepidoptera: Pyralidae). Tropical Agricultural Research and Extension 14, 12-15.

Gupta, A.P., 2019. Immunology of insects and other arthropods. CRC Press.

Janeway, C.A., 1989. Approaching the asymptote? Evolution and revolution in immunology, Cold Spring Harbor Symposia on Quantitative Biology. Cold Spring Harbor Laboratory Press, pp. 1-13. 
Kalyani, S.S., Holihosur, R.S.N., 2015. Toxic effect of crude aqueous leaf extracts of Clerodendron inerme, on the total haemocyte count of sixth instar larva of Helicoverpa armigera $(\mathrm{H})$. International Journal for Innovative Reseach in Science and Technology 1, 221-224.

Khan, M.A., Yamin, W., 2004. Effects of different insecticides formulations and doses againstmaize stem borer in corn fields. Sarhad Journal of Agriculture 20, 609-612.

Klowden, M.J., 2013. Physiological systems in insects. Academic Press.

Kumar, P., Singh, R., Suby, S.B., Kaur, J., Sekhar, J.C., Soujanya, P.L., 2018. An overview of crop loss assessment in maize. Maize Journal 7, 56-63.

Kumar, R., Alam, T., 2017. Bio-efficacy of some newer insecticides against maize stem borer, Chilo partellus (Swinhoe). Journal of Entomology and Zoology Studies 5, 1347-1351.

Malik, M.U., Javed, H., Ayyaz, M., 2015. Evaluation of different groundnut Arachis hypogea L. cultivars against termites, Odontotermes obesus (Rambur) in Rawalpindi, Pakistan. Turkish Journal of Agriculture-Food Science and Technology 3, 448452.

Manjunath, C., Mallapur, C.P., 2017. Impacts of newer molecules of insecticides on management of maize stem borer. Journal of Entomology and Zoology Studies 5, 1424-1428.

Murenga, M., Derera, J.D., Mugo, S., Tongoona, P., 2018. A review of genetic analysis and response to selection for resistance to Busseola fusca and Chilo partellus, stem borers in tropical maize germplasm: a Kenyan perspective. Maydica 61, 111.

Nabeel, M., Javed, H., Mukhtar, T., 2018. Occurrence of Chilo partellus on maize in major maize growing areas of Punjab, Pakistan. Pakistan Journal of Zoology 50, 317-323.

Qamar, A., Jamal, K., 2009. Differential haemocyte counts of 5th instar nymphs and adults of Dysdercus cingulatus Fabr (Hemiptera: Pyrrhocoridae) treated with acephate, an organophosphorus insecticide. Biology and Medicine 1, 116-121.

Rajak, P., Dutta, M., Roy, S., 2014. Effect of acute exposure of acephate on hemocyte abundance in a non-target victim Drosophila melanogaster. Toxicological \& Environmental Chemistry 96, 768776.

Rizwan-ul-Haq, M., Sabri, M.A., Rashid, A., 2005. Toxicity of nicotinyl insecticides on the haemocytes of red cotton bug, Dysdercus koenigii (Fb.)(Pyrrhocoridae: Hemiptera). Journal of Agriculture and Social Sciences 1, 239-241.

Saeed, S., Saeed, Q., Saeed, R., Shafiq, M., Jaleel, W., Ishfaq, M., Naqqash, M.N., Iqbal, M., 2014. Impact of various diets on biological parameters of Chrysoperla carnea Stephen (Neuroptera: Chrysopidae) adults under controlled conditions. Applied Sciences and Business Economics 1, 1-9.

Salt, G., 1970. The cellular defence reactions of insects. Cambridge University Press.

Sidar, Y.K., Deole, S., Gajbhiye, R.h.K., Nirmal, A., 2017. To evaluate the bioefficacy of granular insecticide molecules against pink stem borer. Journal of Entomology and Zoology Studies 5, 1114-1120.

Siddalingappa, Thippeswamy, C., Hosamani, V., Yalavar, S., 2010. Biology of maize stem borer, Chilo partellus (Swinhoe) (Crambidae: Lepidoptera). International Journal of Plant Protection 3, 91-93.

Songa, J.M., Guofa, Z., Overholt, W.A., 2001. Relationships of stemborer damage and plant physical conditions to maize yield in a semi-arid zone of eastern Kenya. International Journal of Tropical Insect Science 21, 243-249.

Strand, M.R., 2008. The insect cellular immune response. Insect Science 15, 1-14.

Ulvila, J., Vanha-Aho, L., Rämet, M., 2011. Drosophila phagocytosis-still many unknowns under the surface. Apmis 119, 651-662. 